\section{Comparison of Management Techniques for Broccoli Production Using a Systems Approach}

\author{
S.B. Sterrett ${ }^{1}$, C.W. Coale, Jr. ${ }^{2}$, and C.P. Savage, Jr. ${ }^{3}$ \\ Eastern Shore Agricultural Experiment Station, Virginia Polytechnic \\ Institute and State University, Painter, VA 23420
}

Additional index words. Brassica oleracea var. italica, market window analysis, production budget, profitability

\begin{abstract}
A systems approach that included production and economic aspects was used to assess broccoli potential as an alternate enterprise for eastern Virginia. Broccoli yield and head quality were improved with 96,400 plants/ha compared to 64,500 plants/ ha. While target populations for the early harvest were achieved with either transplants or direct seeding, plant establishment was significantly reduced for direct-seeding in the main-season harvest (85\% vs. $95 \%$ for transplants). Increased cost of production with transplants resulted in reduced enterprise profit (before taxes) in the early harvest, while improved plant establishment and increased yield with transplants resulted in increased enterprise profit in the main-season harvest. The systems approach assessed market price risk through estimated revenue and yield risk, providing the information needed by growers for risk management decisions associated with broccoli as an alternate enterprise.
\end{abstract}

Using a systems approach, broccoli has been identified as a viable alternative enterprise for Virginia growers when crop yield exceeds 750 cartons $(11 \mathrm{~kg}) / \mathrm{ha}$ (O'Dell et al., 1989; Sterrett et al., 1990a). When yield exceeds 1000 cartons/ha, the broccoli market offers growers profitable margins during the production season in eastern Virginia (Sterrett et al., 1990a).

Since improved yield has been associated with increased plant populations (Chung, 1985; Cutcliffe, 1975; Dufault and Waters, 1985; Gorski and Armstrong, 1985), most commercial broccoli plantings are directseeded (Univ. California Integrated Pest Mgt. Project, 1987). However, the establishment of adequate plant populations with direct

Received for publication 23 July 1990. Seed was kindly provided by Asgrow Seed Co., Kalamazoo, Mich., and by Peto Seed, Saticoy, Calif. The cost of publishing this paper was defrayed in part by the payment of page charges. Under postal regulations, this paper therefore must be hereby marked advertisement solely to indicate this fact.

'Assistant Professor.

${ }^{2}$ Professor, Dept. of Agricultural Economics, Blacksburg campus.

${ }^{3}$ Research Scientist A. seeding has been a continuing problem in both research plots and commercial plantings in eastern Virginia (O'Dell, 1989; O'Dell et al., 1989; Sterrett et al., 1990a, 1990b).

Elson (1989) noted a significant reduction in percent germination of broccoli seed with temperatures exceeding 30C. At 36C, the percentage of germination approached zero. Since the average daily maximum temperature in August, as recorded at the Eastern Shore Agricultural Experiment Station, is 29.5C (Crocket, 1972; NOAA, 1985-1989), poor plant establishment in previous studies (O’Dell, 1989; Sterrett et al., 1990a) may be associated with soil temperatures approaching the lethal germination temperature for broccoli.

Although the influence of plant density on yield and quality has been examined using either transplants (Cutcliffe, 1975; Dufault and Waters, 1985; Gorski and Armstrong, 1985) or direct-seeded broccoli (Chung, 1985; Palevitch, 1970), no direct comparisons between transplant and direct-seeded broccoli for plant establishment, yield, quality, or cost of production have been made.

Before fail broccoli can be recommended as an alternative enterprise in the mid-Atlantic region, the capability of producing a crop of sufficient yield and quality for a reasonable profit must be evaluated. Also, the development of management techniques facilitating adequate plant establishment is needed. Therefore, the objectives of this study were to 1) evaluate the influence of planting technique and plant population on crop establishment and yield; 2) examine climatic influence on crop establishment, yield, and quality; and 3) compare the enterprise profitability of. the planting techniques.

Successful implementation of a new enterprise requires adequate production during an open market window, or when the value of the crop exceeds the cost of production. Since the value of the crop is influenced by the yield (1 1-kg cartons/ha), the price paid to the grower (number of dollars/cartons), and the cost of production (number of dollars/ha), a systems approach was used for these evaluations (Sterrett et al., 1989).

The evaluation of production potential in terms of yield and head quality was combined with economic analysis to determine the most feasible cultural management system. The field study compared the influence of planting techniques, plant population, cultivars, and growing period on yield and quality of broccoli.

The broccoli was planted on a Bojac sandy loam soil (coarse-loamy, mixed thermic Typic Hapludult) at the Eastern Shore Agricultural Experiment Station, Painter, Va. Fertilizer (112N-49P-93K-1.1B, $\mathrm{kg} \cdot \mathrm{ha}^{-1}$ ) and $\alpha, \alpha, \alpha$ trifluoro-2,6-dinitro-N,N-dipropyl-p-toluidine (trifluralin) at $0.56 \mathrm{~kg}$ a.i./ha were incorporated before planting. Three-row plots were planted on beds $1.5 \mathrm{~m}$ wide and $7.6 \mathrm{~m}$ long with either 200 or $300 \mathrm{~mm}$ within-row spacing.

The production and economic analyses were completed for both early (October) and mainseason (November) harvests. Poor head quality associated with average day/night temperature exceeding 24C (O'Dell et al., 1989) restricts the harvest window in August and part of September, while risk of crop loss is greatly increased after the $50 \%$ probability of frost date of 4 Dec. (Crocket, 1972).

The direct-seeded plots were planted earlier (8 and 28 Aug.) than transplants (22 Aug. and 8 Sept. ) so that harvests from the two planting techniques would be concurrent. To minimize the effects of poor seed germination experienced previously, direct-seeded plots were double-seeded (two seeds sown within $25 \mathrm{~mm}$ at each within-row spacing). 
Table 1. Production budget for fall broccoli (200-mm within-row spacing) in eastern Virginia.

\begin{tabular}{lcccc}
\hline \hline & $\begin{array}{c}\text { Transplanted } \\
\text { (plants/ha) }\end{array}$ & $\begin{array}{c}\text { Direct-seeded } \\
\text { (kg seed/ha) }\end{array}$ & $\begin{array}{c}\text { price } \\
(\$)\end{array}$ & $\frac{\text { Cost }(\$ / h a)}{\text { Transplanted Direct-seeded }}$ \\
\hline
\end{tabular}

I. Material cost

\begin{tabular}{|c|c|c|c|c|}
\hline Plants $^{2}$ & 82,523 & & $5.70 /$ thousand & 470.38 \\
\hline Sced & & 1.01 & $352 / \mathrm{kg}$ & \\
\hline Fertilizer, lime, B & & & & 102.72 \\
\hline Pesticides & & & & 75.00 \\
\hline Subtotal I & & & & 648.10 \\
\hline
\end{tabular}

II. Machinery cost (unit cost includes fuel and maintenance)

40 HP tractor with:
3 bottom plow
$2.4-m$ disk
Transplanter (two row)
Seeder (three row)
Sprayer
Fertilizer spreader
Cultivator
Time $\left(h \cdot h a^{-1}\right)$

$\begin{array}{llr}1.68 & 1.68 & 7.74 \\ 0.79(3 \times) & 0.79(4 \times) & 17.19 \\ 6.18 & & 12.50 \\ & 1.98 & 12.44 \\ 0.40 & 0.40 & 14.44 \\ 0.40 & 0.40 & 7.79 \\ 1.98 & 2.47 & 10.19\end{array}$

Subtotal II

$\begin{array}{rr}5.26 & 5.26 \\ 40.76 & 54.35 \\ 77.19 & \\ & 24.58 \\ 5.71 & 5.71 \\ 3.08 & 3.08 \\ 20.14 & 25.17 \\ 152.13 & 118.14\end{array}$

III. Labor cost (allows for calibration, mixing, and equipment cleanup)

\begin{tabular}{|c|c|c|c|c|c|}
\hline \multicolumn{6}{|c|}{ Time $\left(h \cdot h a^{-1}\right)$} \\
\hline Plowing & 1.68 & 1.68 & 4.00 & 6.72 & 6.72 \\
\hline Disking & $0.82(3 \times)$ & $0.82(4 \times)$ & 4.00 & 9.78 & 13.04 \\
\hline Transplanting & $7.41(5 \times)$ & 0.00 & 4.00 & 148.20 & \\
\hline Seeding & 0.00 & 2.47 & 4.00 & & 9.88 \\
\hline Spraying & 0.82 & 0.82 & 4.00 & 3.26 & 3.26 \\
\hline Fertilizing & 0.82 & 0.82 & 4.00 & 3.26 & 3.26 \\
\hline Cultivating & $1.98(4 \times)$ & $2.47(4 \times)$ & 4.00 & 7.90 & 9.88 \\
\hline Harvesting & 123.50 & 123.50 & 4.00 & 494.00 & 494.00 \\
\hline Subtotal III & & & & 673.12 & 540.04 \\
\hline \multicolumn{6}{|c|}{ Quantity $\left(m^{3} \cdot h a^{-1}\right)^{x}$} \\
\hline Irrigation ${ }^{x}$ & 308 & 411 & 42.24 & 313.07 & 417.43 \\
\hline otal production ce & & & & 1786.43 & 1609.80 \\
\hline
\end{tabular}

${ }^{\text {}}$ Plant density, 96,400 plants/ha.

'Five-person crew.

${ }^{x} 308$ and $411 \mathrm{~m}^{3} \cdot \mathrm{ha}^{-1}$ of irrigation for transplants and direct-seed, respectively. Irrigation $\left(103 \mathrm{~m}^{3} \cdot \mathrm{ha}^{-1}\right)$ was applied to direct-seeded broccoli in $25.7-\mathrm{m}^{3} \cdot \mathrm{ha}^{-1}$ increments to promote seed germination and plant establishment.

"Carton costs of $\$ 1.05 /$ carton and icing/shipping costs of $\$ 2.06 /$ carton must be included in total crop costs.

Table 2. Influence of within-row spacing, cultivar, harvest period, and planting techniques on plant population, yield, and size of broccoli.

\begin{tabular}{|c|c|c|c|c|c|}
\hline \multirow[b]{2}{*}{ Variable } & \multirow{2}{*}{$\begin{array}{c}\text { Plant } \\
\text { population } \\
\text { (percentage of target) }\end{array}$} & \multirow{2}{*}{$\begin{array}{c}\text { Yields } \\
\text { (cartons/ha) }\end{array}$} & \multirow{2}{*}{$\begin{array}{c}\text { Average } \\
\text { head wt } \\
(\mathrm{kg})\end{array}$} & \multicolumn{2}{|c|}{$\operatorname{Diam}(\mathrm{mm})$} \\
\hline & & & & Head & Stem \\
\hline \multicolumn{6}{|l|}{ Plant density ${ }^{x}$} \\
\hline 64,500 & 96 & 910 & 0.17 & 111 & 29 \\
\hline 96,400 & 97 & 1060 & 0.15 & 97 & 25 \\
\hline Significance & $* *$ & ** & $* *$ & $* *$ & ** \\
\hline \multicolumn{6}{|l|}{ Cultivar } \\
\hline Premium Crop & 98 & 960 & 0.16 & 107 & 28 \\
\hline Symphony & 95 & 1010 & 0.17 & 101 & 26 \\
\hline Significance & NS & NS & NS & ** & ** \\
\hline \multicolumn{6}{|l|}{$\begin{array}{l}\text { Harvest period } \times \\
\text { planting techniquew }\end{array}$} \\
\hline Early $\times$ transplant & 96 & 910 & 0.14 & 109 & 27 \\
\hline Early $\times$ seed & 110 & 1000 & 0.14 & 107 & 27 \\
\hline Main season $\times$ transplant & 95 & 1090 & 0.17 & 99 & 26 \\
\hline Main season $\times$ sced & 85 & 960 & 0.20 & 99 & 27 \\
\hline Significance & ** & * & * & NS & NS \\
\hline
\end{tabular}

${ }^{2}$ Actual stand count/population density $\times 100$.

'Fourteen-count or $11-\mathrm{kg}$ cartons.

${ }^{x}$ Within-row spacing of 300 and $200 \mathrm{~mm}$, respectively.

"All other interactions were nonsignificant.

Because of low germination rates $(55 \%$ in the early growing period, $42 \%$ in the main season), thinning was not needed.

Plots were harvested weekly starting 4 Oct. and continuing to 28 Nov. The number and weight of heads, as well as head and stem production budgets and costs for direct seeding and transplanting, applying prices and yields to determine revenues for the harvest periods, and estimating the broccoli enterprise profit, before taxes, for each planting method. Assumptions associated with the economic analysis included: 1) transplants produced by grower, rather than purchased, and 2) the estimated scale of production of 2.5-4.1 ha (6-10 acres), since broccoli would be grown as one of several enterprises.

The pricing data were calculated on a weekly basis for the maximum, minimum, and median prices observed on five eastern terminal markets (Federal-State Market News Service, 1983-1987). The three economic scenarios were calculated by relating prices to an optimistic (maximum), an expected (median), and a pessimistic (minimum) situation. Revenues were calculated by multiplying broccoli yields by market prices discounted $20 \%$ for brokerage and marketing fees.

Production budgets were calculated in dollars per hectare using yield estimates from the experimental test plots (Table 1). With the production and economic analyses, the feasibility of the planting techniques at two plant populations were assessed. However, seasonal yield risk associated with the enterprise would require additional evaluation.

Enterprise profit (before taxes) was shown for optimistic, expected, and pessimistic prices for each planting method. Enterprise profit was calculated by subtracting the enterprise costs from revenues derived from each pricing scenario. The enterprise cost reflected both production and marketing costs. To assess the potential of broccoli as an alternate enterprise in eastern Virginia, the estimated value of the broccoli enterprise was compared to that of traditional vegetable enterprises.

Production evaluation. Increased plant density increased yield while decreasing head and stem diameter (Table 2). Average head weight was also lower at the higher plant density, with a greater reduction during the main-season harvest period ( 0.16 vs. 0.21 $\mathrm{kg} / \mathrm{head})$ than during the early crop ( $0.13 \mathrm{vs}$. $0.15 \mathrm{~kg} / \mathrm{head}$ ). These findings concur with those of previous studies (Chung, 1985; Cutcliffe, 1975; Dufault and Waters, 1985; Gorski and Armstrong, 1985).

The influence of planting technique on yield varied with the growing period. Yield from direct seeding exceeded that from transplants in the early harvest, but was lower in the main-season harvest (Table 2). These yield differences reflect the actual plant population (percentage of target population). The reduced plant population with direct seeding in the main-season plot was also reflected in increased average head weight. The average maximum temperature for the 5 days following the early planting was $5 \mathrm{C}$ lower than that of the main-season planting (25C and 30C, respectively). Differences in plant establishment with direct seeding may be related to inhibition of germination during the later planting (Elson, 1989).

Planting technique and plant density also 


\begin{tabular}{|c|c|c|c|c|c|c|c|c|c|c|c|}
\hline \multirow{2}{*}{$\begin{array}{c}\text { Harvest time } \\
\text { and } \\
\text { planting method }\end{array}$} & \multicolumn{8}{|c|}{ Revenue $(\$ / \text { ha by calendar week })^{z}$} & \multirow[t]{2}{*}{$\begin{array}{l}\text { Estimated } \\
\text { revenue }\end{array}$} & $\begin{array}{l}\text { Estimated } \\
\text { cost of } \\
\text { crop }\end{array}$ & \multirow[t]{2}{*}{$\begin{array}{c}\text { Estimated } \\
\text { enterprise } \\
\text { profit }^{\mathbf{x}} \\
\end{array}$} \\
\hline & 40 & 42 & 43 & 44 & 45 & 46 & 47 & 48 & & $(\$ / \mathrm{ha})$ & \\
\hline \multicolumn{12}{|c|}{ Pessimistic } \\
\hline \multicolumn{12}{|l|}{ Early harvest } \\
\hline Transplants & 110 & 1450 & 1440 & 2040 & 850 & 690 & 180 & 80 & 6840 & 5340 & 1500 \\
\hline Direct-seed & 0 & 310 & 1850 & 2820 & 1240 & 1160 & 660 & 140 & 8180 & 5580 & 2600 \\
\hline \multicolumn{12}{|l|}{ Main season } \\
\hline Transplants & 0 & 0 & 0 & 150 & 2400 & 3160 & 1240 & 410 & 7360 & 5430 & 1930 \\
\hline Direct-seed & 0 & 0 & 0 & 0 & 150 & 1880 & 2180 & 1880 & 6080 & 4550 & 1530 \\
\hline Significancey & & & & & & & & & $*$ & --- & NS \\
\hline \multicolumn{12}{|c|}{ Expected ${ }^{\mathrm{w}}$} \\
\hline \multicolumn{12}{|l|}{ Early harvest } \\
\hline Transplants & 150 & 1710 & 1650 & 2400 & 1050 & 830 & 220 & 100 & 8110 & 5340 & 2770 \\
\hline Direct-seed & 0 & 370 & 2110 & 3300 & 1530 & 1400 & 810 & 180 & 9700 & 5580 & 4120 \\
\hline \multicolumn{12}{|l|}{ Main season } \\
\hline Transplants & 0 & 0 & 0 & 170 & 2970 & 3820 & 1530 & 530 & 8720 & 5430 & 3290 \\
\hline Direct-seed & 0 & 0 & 0 & 0 & 180 & 2270 & 2690 & 2430 & 7570 & 4550 & 3020 \\
\hline Sienificance & & & & & & & & & $*$ & $\cdots$ & $*$ \\
\hline
\end{tabular}

${ }^{2}$ First week of October through last week of November.

Calculated by combining cost of production with carton, icing, and shipping costs, which depend on yield [cartons/ha).

'Pessimistic and expected scenarios, based on average maximum, median, -and minimum average price, respectively. Average prices calculated for five terminal markets (Atlanta, Baltimore, Boston, New York, Philadelphia) during 1983to 1987.

"Enterprise profit is calculated as before-tax income.

influenced the percentage of plants producing heads. Broccoli heads were harvested from $90 \%$ of the transplants, but only $79 \%$ of the direct-seeded plants. With 64,500 plants/ha, heads were harvested from $93 \%$ of 'Symphony' plants; with 96,400 plants/ha, heads were harvested from $82 \%$ of 'Symphony'. The percentage of harvestable heads from 'Premium Crop' was $83 \%$, regardless of spacing. The differences in percentage of productive plants may affect harvesting time and harvest efficiency as well as total revenue.

The number of harvests reflects the concentration of head maturity. Fewer harvests were needed in the main season than in the early harvest period (3.9 vs. 5.2, respectively, $P=0.01$ ) and for 'Premium Crop' than for 'Symphony' (4.2 vs. 4.8 , respectively, $P=0.01)$ and for direct seeding than for transplanting (4.2 vs. 4.9, respectively, $P=0.01$ ). While small farm enterprises may harvest the entire crop, those contracting with a harvesting crew would schedule harvest to maximize yield per harvest, with some heads being left unharvested. Concentrated head maturity would increase the percentage of the crop harvested at one time, hence increasing the estimated revenue. The most concentrated head maturity was found with direct-seeded 'Premium Crop', particularly in the main-season harvest. Cutcliffe (1975) also found differences in head maturity between cultivars on Prince Edward Island, although the cultivars differed from those examined here. Cultivar adaptation is regional (O'Dell et al., 1990) and needs to be evaluated within each growing area.

Head quality must also be taken into account in the evaluation of crop management practices. With an average head weight of 0.15 to $0.20 \mathrm{~kg}$, four to five heads per bunch would be needed for an n-kg, 14-count (14 bunches) carton. However, when head diameter exceeds $100 \mathrm{~mm}$, the total diameter of a three-head bunch would exceed the 210mm maximum bunch diameter presently used in the quality standards for Virginia broccoli (Sterrett et al., 1990a). The average head diameter for the low plant density was significantly larger than for the high plant density and exceeded the quality criteria. Since the current quality criteria could not be met with the low plant density, the economic analysis only considered production at 96,400 plants/ha. Additional cultivar evaluations of yield and quality at high plant densities are needed for the development of commercial recommendations.

Economic analysis. Enterprise profitability was influenced by crop yield and seasonal market price (Table 3). However, enterprise profits existed for all scenarios, including the pessimistic one that was calculated using the minimum average prices. Enterprise profits from the expected scenario were 51\% to 59\% greater than the pessimistic one (Table 3), while the estimated enterprise profit for the optimistic scenario was $135 \%$ to $235 \%$ above the estimate for the pessimistic one (data not shown).

Increased estimated revenue and enterprise profit was noted for direct seeding in the early harvest period, while higher estimates were found for transplanting in the main season (Table 3). These trends reflect the differences noted for plant population and yield (Table 2).

Estimated revenue is also affected by the average weekly prices and the concentration of head maturity. For the early harvest, transplant yield was $91 \%$ of the direct-seeded yield, but head maturity was $\approx 1$ week earlier than with transplants. Because of lower average weekly prices in weeks $40--42$, the estimated revenue from transplants was $83 \%$ of direct-seeded in the early season harvest. With the more concentrated head maturity in the main-season harvest, yield from transplants was $114 \%$ of the direct-seeded, with estimated revenue from transplants $111 \%$ of that from direct-seeded broccoli,

The systems approach to broccoli production provides an assessment of market price and production risks. Assessment of these risks provides growers with the information needed for intelligent risk management decisions. Based on this and three previous studies (O'Dell et al., 1989; Sterrett et al., 1990a, 1990b), the production risk is greater than the market risk. Plant establishment has the greatest effect on production risk and significantly impacts enterprise profitability. Since both yield and quality are adversely affected by poor plant establishment, growers need to consider the use of transplants to ensure adequate plant establishment and desirable head size in spite of higher production costs. With access to a transplanter, and a seeder, the maximum profit would be obtained with direct seeding for the early crop and transplanting for the later plantings, provided the grower produces the transplants.

The positive enterprise profit using estimates from the pessimistic or cost conservative scenario is evidence of the viability of broccoli as an alternative enterprise in eastern Virginia. The potential for grower acceptance of broccoli as an alternative enterprise will depend on several factors, including the estimated enterprise profit from traditional crops, efficient use of seasonal labor, rotational needs, and grower interest.

\section{Literature Cited}

Chung, B. 1985. The effects of sowing time and plant density on the once-over harvest yields of broccoli. J. Hort. Sci. 60:57-64.

Crocket, C.W. 1972. Climatological summaries for selected stations in Virginia. Virginia Polytechnic Inst. and State Univ. Water Resources Res. Ctr. BuL 53.

Cutcliffe, J.A. 1975. Effect of plant spacing on single-harvest yields of several broccoli cultivars. HortScience 10:417-419.

Dufault, R.J. and L. Waters, Jr. 1985. Interaction 
of nitrogen fertility and plant populations on transplanted broccoli and cauliflower yields. HortScience 20: 127-128.

Elson, M.K. 1989. Practical temperatures for seeding broccoli. Veg. Growers News 44(1):2

Federal-State Market News Service. 1983-1987. Fresh fruit and vegetable wholesale market prices (by terminal market). U.S. Dept. Agr., Agr. Market Serv., Fruit and Veg. Div., Market News Branch.

Gorski, S.F. and D.M. Armstrong. 1985. The influence of spacing and nitrogen rate on yield and hollow stem in broccoli. Ohio Agr. Res. and Dev. Ctr. Res. Circ. 288:16-18.

National Oceanic and Atmospheric Administration. 1985-1989. Va. Climatic Data Annu.
Summary 95-99 (13):2, respectively.

O'Dell, C.R. 1989. Improving plant stands of direct-seeded fall broccoli. Veg. Growers News 44(3):3.

O’Dell, C. R., R. Morse, P. Ramsey, and A. Borowski. 1989. Field seeded fall broccoli production: A guide for southside Virginia farmers. Virginia Coop. Ext. Serv. Publ. 438-011.

O’Dell, C. R., S.B. Sterrett, C.P. Savage, Jr., and L. Jett. 1990.1989 Fall bunching broccoli cultivar evaluations. Veg. Growers News 44(6):34.

Palevitch, D. 1970. Effects of plant population and pattern on yield of broccoli (Brussica oleracea var. italica) in simple harvest. HortScience 5:230-231.
Sterrett, S. B., C.W. Coale, Jr., T.A. Fretz, and C.R. O'Dell. 1989. Vegetable crop diversification-A systems approach. HortScience 24:539-540.

Sterrett, S. B., J.W. Mapp, Jr., and C.W. Coale, Jr. 1990a. Feasibility of broccoli as a new enterprise-A systems approach. HortScience 25:638-641, 1202

Sterrett, S. B., C.P. Savage, Jr., and R.M. McManus. 1990b. Plant establishment of broccoli as influenced by planting method and plant type. HortScience 25:1076. (Abstr.)

University of California Integrated Pest Management Project. 1987. Integrated pest management for Cole crops and lettuce. Univ. California Div. Agr. and Natural Resources. Publ. 3307. 